\begin{tabular}{lcr}
\hline & ANNALES & \\
& & \\
UNIVERSITATIS MARIAE CURIE-SKLODOWSKA & \\
LOL. II & SECTIO M & 2017 \\
\hline
\end{tabular}

Martin Hetényi

Constantine the Philosopher University in Nitra

\title{
The Hungarian Minority and Confessional Question in the Interwar Czechoslovak Republic and the Slovak State ${ }^{1}$
}

\section{Introduction}

On the ruins of monarchies that ended up among defeated great powers after World War I, and the Russian Empire that was eliminated from the fight due to internal instability even before the final war conflict ended, new "national" states were established. Their creators referred not only to the historical right but also to the right of self-determination. In fact, most of the new states had the boundaries within which a number of nations and nationalities lived. The newly established Czechoslovak Republic could have been a good example.

Hundreds of thousands of Hungarians got into a minority position regardless of their will, after the Czechoslovak Republic was established in 1918. The Hungarian population had to get used to a new, minority identity, new conditions and status. The decision of the powers about becoming a minority was understood by a part of population as a grievance and, thus, they agreed with the requirements for revision of the boundaries. Therefore, they were getting into conflict with the integrity of the state they were living in, as well as with the state power. Moreover, the Czechoslovak propaganda from the period of the First Czechoslovak Republic emphasized that separation from the Austro-Hungarian Empire does not mean separation from a homeland but a separation

1 This article is the result of research project of a scientific grant agency of the Ministry of Education of the Slovak Republic VEGA 1/0615/15. 
from a hostile state formation. However, Hungarian minority in the Republic responded to the change of boundaries by promoting an irredentist conception of relationship towards the Republic.

The life conditions, as well as identity of the Hungarian minority were in the Interwar Czechoslovak Republic governed by legal standards that guaranteed civic equality, political self-fulfilment, school education and cultural life in the native language, while the state favoured civic principles ${ }^{2}$. These rights were fully and intensively utilized by the Hungarian minority. Despite the convenient conditions of its development in a pluralistic democracy, however, for the two decades of the existence of Czechoslovakia and in a tortuous national policy, inappropriate and even discriminatory moments arose - and not only in relation to the Hungarian minority. The problems in relation to ethnic Hungarians were reflected especially in economic and social spheres. Furthermore, the land reform of the 1920s expressed a national-political goal with an attempt to get rid of Hungarian language in the regions of southern Slovakia. The Hungarian inhabitants experienced injustice also regarding the issue of personnel policy in the field of public administration, the issue of nationality, prohibition to use their own national symbols ${ }^{3}$. The number of Hungarian population in the interwar censuses was gradually decreasing, as part of Magyarized population was naturally returning to the original Slovak nationality, and because of assimilation policy and migration. According to the population census conducted in 1921, 650597 inhabitants belonged to Hungarian nationality, which is $21.7 \%$ of the Slovak population. The census in 1930 recorded 585434 inhabitants of Hungarian nationality in Slovakia, i.e. they formed $17.6 \%$ of population. The number of inhabitants of Hungarian nationality, in comparison with the census in 1921, declined by 65000 inhabitants ${ }^{4}$.

During the year 1920, a noticeable migration wave of the Hungarian minority was recorded. Due to the existential problems and not pledging allegiance to the new Republic, 105000 Hungarians were forced to leave the country and the Czechoslovak authorities refused to grant citizenship to more than 40000

2 See: S. Gabzdilová, Školský systém na Slovensku v medzivojnovej Československej republike (1918-1938), Univerzita Pavla Jozefa Šafárika v Košiciach, Košice 2014, p. 50.

3 A. Simon, Vplyv štátoprávnych a politických zmien z konca roka 1938 a zo začiatku roka 1939 na postavenie mad’arskej menšiny (so zvláštnym zretelom na bratislavských Mad'arov), [in:] Rozbitie alebo rozpad?, eds. V. Bystrický, M. Michela, M. Schvarc, Veda, Bratislava 2010, p. 313.

4 See: P. Just, Language problems as the conflict issues of Slovak-Hungarian relations, "Annual of Language \& Politics and Politics of Identity", 2007, no. 1, p. 29; P. Tišliar, Formy organizovania vystahovalectva zo Slovenska po vzniku Československej republiky, [in:] Migračné procesy Slovenska (1918-1948), Belianum, Banská Bystrica 2014, pp. 56-71. 
Hungarians, including the Hungarian clergy. According to the first post-war census in 1921, the Hungarian minority made up $21 \%$ of the Slovak population. The Hungarians inhabited a contiguous territory along the southern border, and in some districts, formed the majority population with the representation of over $80 \%^{5}$.

This text will attempt to answer the following question: Did confessional issues relating to the Hungarian minority reflect political and social development and an overall ratio of the state and churches in the Czechoslovak Republic during the interwar period and after its destroying in the years 1938-1939? Did the members of Hungarian minority become a target of repressive measures from the side of organs in both political systems in Slovakia after 1918? To answer this question, the author of the text will analyze an attitude of the Interwar Republic and the Slovak State towards churches. The confession of Hungarians only slightly differed from the confession of Slovak majority; however, there were different views of confessional issue of Hungarian minority that reflected unhealthy Czech-Slovak-Hungarian relationships. A religious sphere can be included among the activities of a large group of Hungarian minority in Slovakia during the prewar and war period. The author will try identifying the defections of Czech-Slovak-Hungarian relationships.

The text is divided into two parts. The first part will endeavor to outline the overall development of the status of Hungarian minority in the Interwar Czechoslovakia (1918-1939). The paper is dealing with events after the end of World War I. The research of this issue was based on wide source material. The comprehensive perception is more or less absent in Slovak, Czech or Hungarian historiographies. These historiographies provide only rough outlines of these matters without factual detailed discussion and the picture of Hungarians is very fugitive, full of stereotypes which are the sources of misunderstanding and tension. This condition may be the result of both limited access to the sporadically discovered materials. However, there is a lack of information about the difficult journey and experiences of Hungarians in the Czechoslovak and Slovak state systems.

The second part will show the causes of the critical interaction between the Hungarian minority and the Slovak State in the period of 1939-1945. It was mainly related to the overall development of society, especially with gradual liquidation of a pluralistic democracy and a proper attitude towards minori-

5 M. Pekár, Základné východiská menšinovej politiky na Slovensku od roku 1918 po súčasnost', [in:] Národnostná politika na Slovensku po roku 1989, ed. Š. Šutaj, Universum, Prešov 2005, p. 56. 
ties from the Slovak political life that started shortly after the declaration of Slovak autonomy. This part presented by the author is a work based primarily on historical sources. Documents of a central nature have been deposited in the collections of the Slovak National Archive in Bratislava and the Hungarian National Archive in Budapest. Sources for elaboration of this issue at a regional level were provided by the other state archives in Slovakia with theirs regional branches. Operation of the governing party and ethnic majority on the national, and especially regional level, was more difficult to retrace. The majority of documents were destroyed during the liberation of the territory either on purpose or due to objective reasons related to the transit of the front line. Absence of official documents may be partially replaced with contemporary press. Another important source of information regarding the atmosphere and life during the period being researched was contemporary journals and works.

\section{The Hungarian minority in the Interwar Czechoslovakia}

Confessional issues relating to the Hungarian minority partially and properly reflected political and social development, as well as the overall ratio of the state and the churches. The First Act of National Committee after the proclamation of the Czechoslovak Republic on 28 October 1918, the so-called a receptive norm, temporarily set legal continuity with the existing Austro-Hungarian Empire. Besides, a receptive norm took over a previously established legal form of cult affairs. The Kingdom of Hungary distinguished between traditional churches (recognized by a legal standard of higher legal force) and legally recognized churches (by a legal standard of lower legal force). The first ones were permitted by an autonomous law, as they had previously been in operation for a long time. These were the Catholic Church, the Orthodox Church, the Evangelical Church of Augsburg Confession (Lutherans), the Reformed Church (Calvinists), the Israeli Confession of both directions. The Catholic Church performed as a dominant state church, among all of them. Legally recognized churches were recognized by a legal standard of lower legal force. In practice, these churches were not eligible for congrua until 1926. Soon, however, the need to make changes in the structure of some of the churches arose. In 1918, Henrik Geduly, a bishop of the Evangelical Church, appealed through a pastoral letter to Slovak believers to remain in the bond of the Hungarian Church. Besides Geduly, two other pro-Hungarian oriented bishops were at the head of this church in Slovakia. The government promptly intervened against them and since January 1919 , they were prohibited to perform rights and responsibilities associated with their ranks, and consequently emigrated. However, during 1919-1924, 
the Protestants emerged from the Hungarian organisations on the territorial and national principle and, thus, domestic churches were established - among them, the Evangelical Church of Augsburg Confession ${ }^{6}$. In 1924, the Hungarian Evangelical Alliance in Slovakia was established ${ }^{7}$.

The majority of population in Slovakia belonged to the Roman Catholics and during the interwar period, the ratio of this religion remained at the level of $71 \%$. The second largest group recorded was the Evangelic Church of the Augsburg Confession, with more than $12 \%$ of believers. The Greek Catholic Church, mainly associated with that of the Ruthenian ethnic group, amounted to approximately 6.5\%. Regarding these confessions, confessional structure of Hungarians in Slovakia did not vary from the structure of Slovak majority, in particular ${ }^{8}$.

Synergetic links of ethnic and religious identity, in case of the Hungarian minority in Slovakia, were reflected in the Reformed Church that was problematically seeking its position in the new conditions. After Czechoslovakia was established, the ratio of this church rapidly declined (the number of Calvins in Slovakia decreased below 5\%). A substantial part of the member base of this religion consisted of persons who claimed Hungarian nationality. In comparison with 1910, the number of the believers who belonged to the Reformed church decreased by more than 13000 , to about 144-145 000 persons. The difference was caused due to the departure of its believers out of the territory of Slovakia ${ }^{9}$. The vast majority of Calvins expressed a negative attitude towards the Czechoslovak State. Financial support from the government was conditional on the fact that they would establish an independent Slovak seniority and the clergy would pledge allegiance to the Republic. When they found out that the Czechoslovak authorities will not provide them with wages or financial support for the parishes, the Calvins, influenced by lower clergy, decided to negotiate with the institutions of the Czechoslovak Republic. In 1921, following the agreement of representatives of the Reformed Church with the Minister for Administration of Slovakia, they closed a deal to cast off the influence of the church hierarchy

${ }^{6}$ M. Kadlecová, Pomèr státu a církví, [in:] Dějiny Československého státu a práva (19181945), Masarykova univerzita, Brno 1992, p. 70.

7 See: A. Bartlová, Formovanie vzṫahu československého štátu k trom cirkvám, pôsobiacim na Slovensku, [in:] Verbum historiae I. Vydavatel'stvo Michala Vaška, Prešov 2009, pp. 98-120.

8 B. Šprocha, P. Tišliar, Demografický obraz Slovenska v sčitaniach ludu 1919-1940, Tribun EU, Brno 2012, p. 191. See also: B. Šprocha, P. Tišliar, Demogeografický profil náboženského vyznania obyvatelstva Slovenska za posledných 100 rokov, [in:] Populačné štúdie Slovenska, Muzeológia a kultúrne dedičstvo o.z., Bratislava 2014, pp. 111-187; P. Tišliar, To historical demography and demographic history in Slovakia, "Historický časopis", 2011, no. 2, pp.179-185; P. Tišliar, Historical demography in Slovakia in the last century, "European Researcher", 2012, no. 3, pp. 259-265.

9 B. Šprocha, P. Tišliar, Demografický obraz... op. cit., p. 202. 
in Hungary. Soon, the Calvinist clergymen, as well as the priests of other confessions, were forced to pledge allegiance. Following this act, they began to receive regular wages and in 1923, an independent Reformed Christian Church in Slovakia was established.

The Czechoslovak national politics gave ecclesiastical authorities the possibility to implement Hungarian language in the church services and accompanying actions. As a result of historical development, the relationship of the state towards the Roman Catholic Church in Slovakia was dominant. While setting the borders during the Paris Peace Conference, the borders of church districts were not considered. Many dioceses had their head offices abroad and on the contrary, the Czechoslovak ordinaries interfered with their power abroad. At the beginning of 1919, the Bishop's offices in Slovakia were in the hands of Hungarian bishops or vicars who refused to put up with the fall of the Hungarian Kingdom and they instructed their priests in the same way. Augustín Fischer-Colbrie, a bishop from Košice, who refused a forced Magyarization in the past and upheld for persecuted priests from Slovakia, was an exception. This situation was tried to be changed by the activists from among Slovak catholic clergy, who in November 1918, founded Clerical council, seeking for consolidation of the religious situation through creation of Catholic autonomy in Slovakia. Besides Slovak priests, the pressure on Hungarian episcopate was pushed by the state apparatus, as well. As the result, the bishops of Nitra and Banska Bystrica were forced to leave their offices, the other ordinaries died in a short time (bishops of Rožňava, Košice and Spiš). Štefan Novak, a Greek-Catholic bishop of Prešov eparchy, who refused to pledge allegiance to the new Republic, had previously emigrated to Hungary ${ }^{10}$. Similar situation occurred in several abbeys and monastic societies. The state had to promptly respond to the transport of church property to Hungary. Since 1919, protection against its transport and thieving was determined by several orders of the Minister for Administration of Slovakia. These were administered by commissions chaired by a member of episcopacy of the specific territory.

The Treaty of Trianon, the peace agreement signed on 4 June 1920, defined the borders of Czechoslovakia. In 1921, the Pope responded by establishing official diplomatic relations with Czechoslovakia and by appointing three Slovak bishops. Following this act, other dioceses in Slovakia were gradually filled by new bishops. However, considerable obstacles of legal, personal, and partially political character still remained a key problem in stabilizing intra-clerical life

${ }^{10}$ J. Coranič, Vztáah katolíckej cirkvi a štátu na Slovensku v rokoch 1918-1938, “Theologos”, no. 2, 2008, pp. 186-187. 
in the following years. Many priests were of Hungarian nationality and even though they had pledged allegiance to the Republic, they did not want to give up their pro-Hungarian way of thinking.

A whole series of questions indicates a significant incongruity of the state towards religious life, whether it is an urgent requirement of many political parties to separate state from the church or the establishment of Cyril and Methodius Catholic Theological Faculty in Olomouc and Huss Evangelical Theological Faculty in Prague (both of them funded by the state) or Marriage Law of 1919, in which the state retained the right of churches to substitute activities of state authorities. The thoughts of political representations related to separation of the church from the state, that still has not been realized, were influenced by several arguments about positive and negative consequences. For example, the loss of influence over the appointment of high-rank church dignitaries would enable a nomination of pro-Hungarian oriented bishops in Slovakia and Ruthenia that would markedly strengthen separatism at the time. Without the state supervision, cleric education could have been unfavourable for the state. These problems indicated a complex jurisdictional relationship between the church and temporal power.

The Constitution of 1920 contained regulations that modified relationship of the state and churches - freedom of conscience and confession allowed entire religious freedom, equality of all confessions and others. Other laws were handling the most urgent religious-political issues but it was impossible to process some of them without the cooperation of Vatican - especially regarding the division of church property and delimitation of dioceses which were considerably important for the sovereignty of Czechoslovakia. The interventions to the religious education were equally important. The Congrua Law (that modified salaries for clergy) adopted in 1926, separated congrual churches and parishes (the state provided clergy with a monthly financial income to ensure their existential minimum) and the ones that were subsidized (the state provided churches with the subsidies) ${ }^{11}$.

Multiannual negotiations with the Roman Curia led to the adoption of Modus Vivendi in 1928. Modus Vivendi set that no part of the Republic will be subordinated to an ordinary based abroad and no diocese shall exceed national borders. The agreement also handled church property administration. Regarding the issue of nomination rights - the Prague's government had to be notified of the names

${ }^{11}$ The congrual churches in Slovakia included the Catholic Church, the Evangelic Church of the Augsburg Confession, the Reformed Evangelic Church, the Orthodox Church and the Jewish religious communities. 
of dignitaries before they were appointed by the Holy See, in order to make sure it did not have any objections to the selected persons. One of the agreement's articles set a pledge of allegiance to Czechoslovakia that needed to be performed by the ordinaries after being nominated by curia and before accession to their offices. Even the clergy had to pledge allegiance to the Republic.

A contemporary legislation of Czechoslovakia created quite favourable conditions for usage of mother tongue in education, culture and religious ceremonies. To sing Hungarian national anthem and some religious songs with the irredentist undertone in public and in the churches was considered to be punishable. According to Act No. 50/1923 Coll., $\mathbb{\$} 14$, it was a misdemeanour of public peace disturbance. Despite an existing ban, public singing of Hungarian national anthem occurred quite frequently, which led to the numerous incidents. It was nothing extraordinary to sing the Hungarian anthem at the end of masses in church, mainly during Hungarian feasts, which the offices considered as a seditious provocation followed by police investigation ${ }^{12}$.

For humans, culture and confession is not only a presumption of their creative activity but in a sense, it is also a prison whose boundaries cannot be crossed. It relates to a relationship towards past cultures, as well as towards parallelly existing ones. A fellow-feeling among "all Hungarians" is also demonstrated by commemoration of St. Stephen's tradition ${ }^{13}$. To a great extent, the inhabitants stopped attending celebrations, as many Hungarians in Slovakia retreated from outer manifestations that provoked state authorities in order to avoid accusations of irredentism and consequently, to avoid penalization and retorsions ${ }^{14}$.

Unsatisfactory solution of Slovak, German and Hungarian problem of nationhood did not help to solve global problems at all - international problems that erupted in the late thirties. Hungary's foreign policy was, throughout the entire interwar period, characterized by the efforts to revise the Treaty of Trianon. ${ }^{15}$ The Hungarian-Czechoslovak antagonism, beside the conflicts with Hit-

12 R. Letz, Katolícka cirkev a vznik Slovenského štátu, [in:] Rozbitie alebo rozpad? Historické reflexie zániku Česko-Slovenska 1939, eds. V. Bystrický, M. Michela, M. Schvarc, Veda, Bratislava, 2010, pp. 410-411.

13 The local Hungarian press emphasized: "Wherever Hungarians have lived to date, on 20 August, churches will become overcrowded”, Prágai Magyar Hírlap, August 19, 1923, p. 1.

${ }^{14}$ M. Michela, Percepcia svätého Štefana na Slovensku v medzivojnovom období, [in:] Pamét’ míst, událostí a osobností: historie jako identita a manipulace, Historický ústav AV ČR, Praha 2011, p. 234.

${ }^{15}$ See: A. Feriancová, (Ne)nájdená bezpečnost'. Československo, Nemecko a úpravy medzinárodného systému v Európe 1922-1926, Univerzita Konštantína Filozofa, Nitra 2010. 
ler's Germany and Beck's Poland, was internationally seen as one of the factors seriously threatening the existence of Czechoslovakia ${ }^{16}$.

The governmental movements in Europe in the late thirties enabled Hitler to resolve the so-called Czechoslovak question, assisted by Hungarian government circles in their permanent effort to change Trianon borders. Significant territorial changes, heading to abridgment of Slovak territory, began with the arbitration of German and Italian government on November 2, 1938 in Vienna ${ }^{17}$. A few months later, Hitler totally destroyed the Czechoslovak Republic, and for his personal gain allowed to create the Slovak state (March 14, 1939). Its political system created differentiated conditions for the existence of its ethnic minorities.

\section{Religious conditions of the Hungarian minority in Slovakia after 1938}

The status of the Hungarian minority was specific. Its development was mainly related to the overall development of society, especially with gradual liquidation of a pluralistic democracy and a proper relationship towards minorities from the Slovak political life that started shortly after the declaration of Slovak autonomy (October 6, 1938). Undemocratic actions against autonomy not even fell under political nationalism of totalitarian Hlinka's Slovak People's Party; they were also determined by the Slovak-Hungarian relation. Close ties of Hungarian minority to their motherland were obvious. Even though the Kingdom of Hungary was an official ally of the Slovak state in the Triple Pact since fall of 1940, in the public opinion of Slovak society (supported by the propaganda of Slovak government) it only represented a spectre with the features of revisionism.

After first Vienna Arbitration, the number of Hungarians in the reduced territory of Slovakia considerably declined to $67502(2.5 \%) .{ }^{18}$ Religious orientation of ethnic Hungarians varied from the Slovak majority only in eastern Slovakia,

${ }^{16}$ D. Čierna-Lantayová, Podoby česko-slovensko-mad’arského vztahu 1938-1949, Veda, Bratislava 1992, p. 11; See also: A. Kičková, Runcimanova misia a Československo v roku 1938, [in:] České, slovenské a československé dějiny 20. století IV. UHK, Hradec Králové 2009.

17 See: L. Deák, Viedenská arbitráž 2. novembra 1938. Dokumenty I.-III., Matica Slovenská, Martin, 2002-2006.

${ }^{18}$ Slovenský národný archív (Slovak National Archive, SNA), Collection of Ministerstvo vnútra, Box 33, File 379/39. See also: Zprávy Štátneho plánovacieho a štatistického úra$d u, 1946$, vol. 1, no. 1, pp. 17-18. V. Bačová, Etnická identita a historické zmeny. Štúdia obyvatelov vybraných obcí Slovenska, Veda, Bratislava 1996; O. Csampai, Viharvert nemzet-tudat. Az identitástudás és érzésvilág problemái Zoboralja magyár falaiban, O. Csampai publishing, Bratislava 1994; B. Šprocha, P. Tišliar, Štruktúry obyvatel'stva Slovenska v rokoch 1919-1940, Infostat, Bratislava 2009; A. Zelová, Etnická identita mad’arskej menšiny na Slovensku, [in:] Etnické menšiny na Slovensku, ed. V. Paukovič, Spoločenskovedný ústav SAV, Košice 1991, pp. 43-52. 
where the majority of Calvins claimed Hungarian nationality. The ethnic Hungarians were given an opportunity to attend worships held in Hungarian language (a liturgical order was generally kept from before 1939). Hungarian religious ceremonies (concerning Catholic ceremonies, only sermons and Holy Scriptures readings were held in national languages) were held in 54 municipalities ${ }^{19}$. The Hungarians actively, and partly successfully, asked for re-implementation of Hungarian religious ceremonies in the places where their status for various reasons was disrupted. In an effort to gain right to serve new masses in Hungarian language, the offices, public majority and ecclesiastical authority were of different opinions. The increase of activities and national demands of Hungarian minority, after the military successes of German and Hungarian army in spring 1941 , could be seen in the organization of various religious celebrations ${ }^{20}$. A defensive principle of reciprocity and national onset of the state apparatus can be seen in the attempt to limit Hungarian worships and processions ${ }^{21}$. It might not be a paradox that the Hungarians participated in the celebrations, related to the feasts symbolizing Slovak nationhood, only on a small scale ${ }^{22}$.

The question concerning the status of the Hungarians in Slovakia was in practice conditioned by the question of legal status of the Slovaks in Hungary. The Hungarian minority could unite politically and in the associations, even though within limits ${ }^{23}$. One of the program tasks of Hungarian intelligence, despite the restrictions, focused on the development of cultural and sport life, as well as education of the Hungarian minority. Considerable contribution is attributed to Hungarian clergy, active in the Christian churches in Slovakia. The Hungarian believers and many representatives of clergy, who could rely on good relationships with the representatives of the Bishop's offices, often expressed their pro-Hungarian or anti-Slovak attitudes and moods.

Christian churches played an important role in the functioning of the Slovak State. Mainly the Roman-Catholic Church $^{24}$ was closely linked with state

${ }^{19}$ State Archive Nitra, Collection of Župný úrad, Box 59, File 547/II-2/ŠB/42.

${ }^{20}$ For example, the local Hungarian press informed about it in Magyar Hírlap, April 8, 1942, p. 4.

${ }^{21}$ State Archive Bratislava, Collection of Bratislavská župa, Box 28, File 352/42. See: Vietor M., Dejiny okupácie južného Slovenska, Vydavatel’stvo SAV, Bratislava 1968, p. 94.

${ }^{22}$ A. Mikulášová, M. Palárik, Oslavy piateho výročia vzniku slovenského štátu v nitrianskom regióne, [in:] Slovenské národné povstanie, ed. M. Syrný, Múzeum SNP, Banská Bystrica, 2014, p. 567.

${ }^{23}$ M. Pekár et al., Ethnic Minorities in Slovakia in the years 1918-1945, Universum, Prešov 2011, p. 132.

${ }^{24}$ See e.g. J. Dolinský, Cirkev a štát na Slovensku v rokoch 1918-1945, Dobrá kniha, Trnava 1999; M. Hetényi, I. Ivanič, Poznámky k šíreniu kultu sv. Cyrila a Metoda v rokoch 1939-1945 
and party structures - ideologically and personally, as well. Tens of its priests were active officials of Hlinka's Slovak People's Party, church dignitaries were the members of congress who laid their claim to merits in creation of the Slovak State and remained its reliable support. Due to high religiosity of Slovak population and church authority, such attitudes were encouraging a political identity of regime ${ }^{25}$. Besides a strong support of diocesan and parish area of church hierarchy arrangement, the government assisted in the development of religious orders and congregations.

There were four Catholic episcopates and two apostolic administrations in Slovakia at that time. However, an autonomous Slovak ecclesiastical province did not originate ${ }^{26}$. Following territorial changes related to Vienna Award, Vatican came up to a new delimitation of dioceses in July 1939. Parts of Košice, Rožňava and Satmar Roman Catholic episcopate that remained in the territory of the Slovak State were administered by Jozef Ćársky, a Roman Catholic bishop from Prešov. On the other hand, the parts in the arbitration area were distributed among episcopates based in Hungary.

A clergy response to a new situation after Vienna Award was diverse - not only in the Catholic Church there was a certain differentiation to some questions of social life ${ }^{27}$. The Roman Catholic ecclesiastical authority (whose inclination to authoritarian regime was often conditioned by personal political conviction, as well as taken as a fact) retained its sovereignty over the matters with parsons even though the dignitaries believed it would be more accommodating towards the church. It even resisted restrictive pressure proposals of the state authorities.

na príklade mesta Nitra, [in:] Život v Slovenskej republike: Slovenská republika 1939-1945 očami mladých historikov IX, ÚPN, Bratislava 2010, pp. 336-345; P. Mulík, Katolícka cirkev a politika Slovenskej republiky 1939-1945, [in:] Slovenská republika (1939-1945), Matica slovenská, Martin 2000, pp. 101-113; I.A. Petranský, Katolícka cirkev na Slovensku a povstanie roku 1944, [in:] Slovenská republika 1939-1945 očami mladých historikov III, UCM, Trnava 2004, pp. 49-78; Petranský I. A., Katolícka cirkev v obdobi prvej Slovenskej republiky, [in:] Slovenská republika 1939-1945 očami mladých historikov I, UCM, Trnava 2002, pp. 30-49; K. Sidor, Šest́ rokov pri Vatikáne, PA, Scranton 1947; V. Vaško, Neumlčená. Kronika katolické církve v Československu po druhé světové válce I, Zvon, Praha 1990; Vatikán a Slovenská republika 1939-1945. Dokumenty, eds. I. Kamenec, V. Prečan, S. Škorvánek, Slovac Academic Press, Bratislava 1992.

${ }^{25}$ I. Kamenec, Slovenský stát 1939-1945, Anomal, Praha 1992, pp. 34-36.

${ }^{26}$ See: P. Mulík, Úsilie o zriadenie slovenskej cirkevnej provincie od roku 1939 a jej vývoj po súčasnost', [in:] Katolícka cirkev a Slováci. Úsilie Slovákov o samostatnú cirkevnú provinciu, Bernolákova spoločnost', Bratislava 1998, pp. 63-85.

${ }^{27}$ See: M. Vilhan, Postoje katolíckej cirkvi na Slovensku k politickým režimom v rokoch 1939-1951, [in:] SNP 1944 - vstup Slovenska do demokratickej Európy, Múzeum SNP, Banská Bystrica 1999, pp. 384-405. 
The church dignitaries only exceptionally intervened in clerical activities, in ostentatious cases, a priest was sent to retirement, transferred to another place of work, or was replaced by a loyal person.

Only in exceptional cases, the decision of the Roman Catholic bishop, concerning a liturgical order, was altered by the state authorities - against the Hungarian church ceremonies. State security headquarter, the scope of which also included state security as well as political and minority issues, intercepted the permission of Hungarian worships in Bernolakovo in 1942, issued by the bishop of Trnava. In Humenne, the authorities managed to ban Hungarian worships in the Roman Catholic parish. Similarly, state authorities accomplished the annulment of Calvinist worships in Hungarian language in Svinica near Trebišov. ${ }^{28}$ Regarding priests of other Christian churches, who also played an important role in the religious environment of Hungarian community, the state apparatus could proceed more vigorously as their connection with state was not as strong as in the case of the Roman Catholics.

Prešov was the seat of the Greek Catholic Eparchy and believers from all over the Slovak Republic were liable to Peter P. Gojdič, the bishop of Prešov. The relationship of Gojdič and the Greek Catholics of Ruthenian nationality to the Slovak State was burdened by an ethnic undertone. The attempts of state authorities to Slovakize Ruthenian environment, and on the other hand, an aversion of the bishop to grant emancipation rights of Slovak believers led to permanent tension between the state apparatus and Ruthenian clergy, while a Hungarian question was often misused. The local state authorities warned the superior organs about an alleged agitation of the Greek Catholic clergy coming from the residence of bishop Gojdič and heading to affiliation of Ruthenian areas to Hungary ${ }^{29}$. Mainly in 1939, the state administration limited such an agitation by arrests and imprisonment of some malcontents in a custodial camp. Twenty persons out of the Greek Catholic priests from Prešov were considered by the authorities as Magyarons (Magyarized non-Magyars), specifically from the Bishop's office ${ }^{30}$.

The attitude of official representatives of the Evangelical Church towards regime of the Slovak State was an expression of a kind of loyal opposition. In the political life, they were sort of passive ${ }^{31}$. From an organizational perspective, we

${ }^{28}$ State Archive Prešov, Collection of Šarišsko-zemplínska župa, Box 117, File 82/3c/42.

${ }^{29}$ SNA, Collection of Ministerstvo vnútra, Box 16, File 7188/39 prez.

${ }^{30}$ State Archive Prešov, Collection of Šarišsko-zemplínska župa, Box 113, File 1138-3c/41.

${ }^{31}$ D. Baranová, Evanjelická cirkev a.v. v protifašistickom odboji na Slovensku, [in:] SNP 1944 - vstup Slovenska do demokratickej Európy, Múzeum SNP, Banská Bystrica 1999, pp. 145154; V. Šmihula, Postoj evanjelickej a.v. cirkvi k vojnovému Slovenskému štátu, [in:] SNP 1944 - 
can mention an interesting moment when its management, as the only confession in Slovakia in the monitored period, split according to ethnic principle. The Evangelical believers of German nationality were by a religious law, handed down by Synod of the Evangelical Church in Slovakia on Juny 14, 1939, excluded from its alliance so that they could organize themselves independently, on the basis of an ethnic principle. However, the governance had reciprocally never admitted an independent administration of Hungarian Evangelical Church in Slovakia. The governance subordinated Hungarian Evangelical Association of Augsburg Confession in Slovakia to a German church administration. It brought tension, as the German representatives of German-Hungarian Evangelical Church refused to confer the corresponding rights for Hungarian liturgical language to the Hungarian part ${ }^{32}$. Hungarian believers of Evangelic confession showed dissatisfaction with this fact and required their Evangelic Church to remain organized within General Slovak Evangelical Church ${ }^{33}$.

The authorities continued to put the accent on reformed - Calvinist Church, as well. The Reformed Church in Slovakia was before Vienna Award managed by Vojtech Sörös, a bishop of "Preddunajský district". Since he remained active in Lučenec after Vienna Award, he decided to delegate his episcopal powers to ecclesiastical councils that remained from his district in the territory of the Slovak State. It is likely, though, that Sörös kept a certain influence over the organization of the Reformed Church in Slovakia ${ }^{34}$. The Slovak government was, therefore, trying to restrain Hungarian influence among the Calvinists by creating a new Organizing committee of the Reformed Church in Slovakia in November 1939. The Hungarian Calvinists, living mostly in the eastern part of the state, however, did not recognize the supremacy of the Organizing committee ${ }^{35}$.

The inhabitants of Hungarian nationality had an opportunity to attend worships held in Hungarian language, while the status and number of Hungarian worships was generally the same as before 1939. Overall, Hungarian religious ceremonies were at the beginning of the monitored period held in 54 municipalities. In the areas with prevalence of other nationalities, worships were also held in other languages, in addition to Hungarian one. 17 municipalities in the

vstup Slovenska do demokratickej Európy, Múzeum SNP, Banská Bystrica 1999, pp. 463-467; L. Suško, Evanjelická cirkev augsburského vyznania na Slovensku 1938/1939 v zrkadle cirkevnej tlače, „Historický časopis”, 2001, no. 1, pp. 63-84.

${ }^{32}$ SNA, Collection of Ministerstvo školstva a národnej osvety, Box19, File 130605/40.

${ }^{33}$ State Archive Banská Bystrica, Collection of Pohronská župa II., Box 4, File 1174/40.

${ }^{34}$ State Archive Bratislava - Modra, Collection of Okresný úrad v Bratislave, Box 27, File 2659/39 prez. See Magyarok 1995: 87-90.

${ }^{35}$ State Archive Banská Bystrica, Collection of Pohronská župa II., Box 27, File 703/43. 
regions of Nitra and Zlate Moravce, with the prevalence of Hungarian community, usually performed Hungarian masses only. However, following modifications of Catholic Bishop authorities (until the beginning of 1941), the municipalities with relevant interest of Slovak minority held Slovak worships as well, without any special restriction of Hungarian ones ${ }^{36}$.

Mainly in municipalities, where the status of Hungarian worships was for various reasons disrupted, the Hungarians actively and partly successfully asked (not only through Slovak authorities) for their restoration. As far as they were trying to win the right to serve new masses in Hungarian language, the authorities, majority public and ecclesiastical authority did not find understanding towards it. The nationalist orientation of state apparatus, its Slovakised pressure and reciprocal principle was reflected in an attempt to limit the action of Hungarian worships and pilgrimages. Regarding permissions, the authorities were putting various administrative obstacles, under the pretence that the public order could be disrupted, for instance. Moreover, they were following the participants of St. Stephen's Day celebrations in Hungary and prevented them from crossing the borders ${ }^{37}$.

In case the ecclesiastical authorities lost control over the actions of the individual priests, the state power had to respond. According to many archival documents, the rate of penalties (an arrest without indictment ${ }^{38}$, banishment from the territory of the Slovak State ${ }^{39}$, a financial penalty, a detention of wages, a constraint on moving to Hungary, a call into military service, a disposal or refusal of important documents, restriction of travelling and others) was dependent on international events and development of Slovak-Hungarian relationships. Due to the protection of influential ecclesiastical authorities, as well as support of influential local groups, the number of punished priests did not reach massive proportions. The mutual links of municipal officials and parsons often had economic background - for example, the members of Hlinka's Slovak People's Party advantageously rented church properties from parsons. At least 5 clergymen ended up in prison, without being sentenced. Prosecutions of politically motivated offenses were due to amnesty gradually discontinued.

${ }^{36}$ State Archive Nitra, Collection of Župný úrad, Box 59, File 547/II-2/ŠB/42.

${ }^{37}$ SNA, Collection of Ústredňa štátnej bezpečnosti, Box 518, File 33741/43.

${ }^{38}$ See: J. Rychlík, Perzekúcia odporcov režimu na Slovensku 1938-1945, [in:] Slovenská republika 1939-1945 očami mladých historikov IV. Univerzita Mateja Bela, Banská Bystrica 2005, pp. 119-134.

${ }^{39}$ Magyar National Archive, Collection of Miniszterelnökség kisebbségi osztály, Box K-28, Files 152, 252, 21979/42. 
State power had a sufficiently built administration for monitoring and damping of activities of various groups, as well as individual citizens, including priests. At the end of 1941, the district authorities, at the behest of the State security headquarter, completed a control evidence of priests in the Hungarian communities. This list included data on their political activities, reliability and thinking, as well as knowledge of Slovak language. The nature of their perception shifted its position from milder forms to radically xenophobic proposals. Overall, there was a discontent over their political thinking. Since fall 1938, the People's state power reviewed by its pro-Hungarian political way of thinking at least 132 priests - 53 Roman Catholics, 44 Greek Catholics, 18 priests of the Evangelical Church of the Augsburg Confession, 15 Calvins, and one of them of Orthodox confession.

It was not extraordinary at all that the priests involved themselves politically, as well as in the associations. Within the Hungarian party in Slovakia ${ }^{40}$ (the only allowed party of Hungarian minority), the clergy was exposed and that was mainly after its official registering in November 1941 and its expansion. All over the state, priests helped to organize population of Hungarian minority into activities, especially in the cultural, educational, sport and social field. However, due to international events at the beginning of 1943 and because of the loss of hopes of Hungarian victory in the war, the activity of most members of the Hungarian Party, including active priests, waned into passivity.

After the war, Slovak-Hungarian relationship encountered one of the problems - a question of national minorities in Slovakia, or Czechoslovakia. The change of political system brought not only different understanding of Hungarian minority based on the principle of collective guilt ${ }^{41}$, but also new positional weakening of Christian confessions in the role of society and state.

${ }^{40}$ I. Molnár, Život a martýrska smrt̉ Jánosa Esterházyho, Méry Ratio, Šamorín 2012, pp. 36-37; See also: G. Popély, A kisebbségi magyar pártpolitika megújulása a harminc évek a első felében, "Regio", 1990, no. 3, pp. 97-132; A. Tóth, L. Novotný, M. Stehlík, Národnostní menšiny v Československu 1918-1938, Univerzita Karlova, Praha 2012, p. 91, 94; P. Zelenák, Krajinská krestansko-socialistická strana, [in:] Politické strany na Slovensku 1860-1989, ed. L. Lipták, Archa, Bratislava 1992, pp. 150-158.

${ }^{41}$ See e.g. N. Bárdi, Cs. Fedinec, L. Szarka, Minority Hungarian communities in the twentieth century, Atlantic Research and publications Inc., New York 2011; D. Čierna-Lantayová, Otázka národnostných menšín vo vztảau medzi Česko-slovenskom a Madarskom 1944-1948, [in:] Národnosti na Slovensku, Veda, Bratislava 1993, pp. 19-25; Š. Šutaj, Mad’arská menšina na Slovensku v 20. storočí, Kalligram, Bratislava 2012; Š. Šutaj, Mad’arská menšina na Slovensku v rokoch 1945-1948, Veda, Bratislava 1993; K. Vadkerty, Madarská otázka v Československu 1945-1948. Dekréty prezidenta Beneša a ich dôsledky na deportácie a reslovakizáciu, Kalligram, Bratislava 2002. 


\section{Conclusion}

The aim of the present paper is to map the changes that took place in religious problems of the Hungarian minority in Slovakia in the years 1918-1945. The results of this work are mainly based on the archive and literature research, as well as the research of press in that time. The very starting point of this essay supposes that the members of Hungarian minority became a target of special repressive measures from the side of Czechoslovakian and Slovakian state organs. The analysis has confirmed this conviction. The author not only comments the defections of Czech-Slovak-Hungarian relationships but he also identifies them.

Christian churches, i.e. Catholics, Protestants and Orthodox Church, played an individual role in the system of the Czechoslovak Republic and the Slovak State. Toleration is not only a moral but also political ideal that determinates a pluralistic form. The interwar Czechoslovakia was based on the civic principle of understanding of the liberal state. Following the initial problems, the government was looking for a common consensus with the churches. Ethnical minorities could perform religious life, unless they respected the changed political conditions. However, many members of the Hungarian minority, clergy as well, could not reconcile with their status. After 1938, due to international events, only a small part of Hungarian minority stayed in Slovakia. Any efforts of a new regime with totalitarian features to limit church life of the Hungarian minority, however, encountered the revolt of some church dignitaries, as well as the principle of reciprocity. Both political systems in Slovakia after 1918 closely followed the actions of Hungarian minority and sometimes even responded hard. Many problems confirm a noticeable contradiction in the relationship among state, churches, Hungarian and Slovak minorities. Very often pro-Magyar tendencies occurred among the clergy. Separate fragments of state and political machinery on central and local level reported about their different endorsements; and they were trying to eliminate, or restrict them in different ways. Persecution of pro-Magyar oriented clergy was mainly connected with reciprocal steps of Slovak government, and police actions got individual character. According to the point of view, the worst police action was a deportation of the Magyars, among them also the priests, at the turn of the years 1938/1939. After the consolidation of Slovak State position, the endorsements of pro-Magyar-oriented priests were not so strong. In case of improper nationalist fulminations of the clergy, the state bodies punished them also by other standard methods like financial penalties, or by suspension or not giving the important papers, etc. Hungarian nationality citizens could attend the divine services in Hungarian, while their number was generally the same as before the year 1939. In some villages, the Hungarian church services were for 
some reasons disturbed, and so Hungarians very actively asked for their restoration. However, if they wanted to obtain the right to celebrate new services in Hungarian language, the authorities, majority public and religious representatives did not allow it. The epicenters of conflicting situations caused by clergy were not only villages with predominant Hungarian community, but also the parishes, were Slovaks represented the majority. It is necessary to notice that it was also vice versa, i.e. in some villages with Hungarian majority, there were pro-Slovak-, or pro-German-oriented priests. Of course, it does not automatically mean that there should have been some conflicts. Also good relationships between priests of Hungarian nationality and Slovaks were not exceptions.

\section{Bibliography}

- Bačová V., Etnická identita a historické zmeny. Štúdia obyvatelov vybraných obcí Slovenska, Veda, Bratislava 1996.

- Baranová D., Evanjelická cirkev a.v. v protifašistickom odboji na Slovensku, [in:] SNP 1944 - vstup Slovenska do demokratickej Európy, Múzeum SNP, Banská Bystrica 1999.

- Bárdi N., Fedinec Cs., Szarka L., Minority Hungarian communities in the twentieth century, Atlantic Research and publications Inc., New York 2011.

- Bartlová A., Formovanie vztahu československého štátu k trom cirkvám, pôsobiacim na Slovensku, [in:] Verbum historiae I. Vydavatel'stvo Michala Vaška, Prešov, 2009.

- Coranič J., Vzṫah katolíckej cirkvi a štátu na Slovensku v rokoch 1918-1938, „Theologos", 2008, no. 2.

- Csampai O., Viharvert nemzet-tudat. Az identitástudás és érzésvilág problemái Zoboralja magyár falaiban, O. Csampai publishing, Bratislava 1994.

- Čierna-Lantayová D., Otázka národnostných menšín vo vztahu medzi Česko-slovenskom a Madiarskom 1944-1948, [in:] Národnosti na Slovensku, Veda, Bratislava, 1993.

- Čierna-Lantayová D., Podoby česko-slovensko-mad’arského vztahu 1938-1949, Veda, Bratislava 1992.

- Deák L., Viedenská arbitráž 2. novembra 1938. Dokumenty I.-III., Matica Slovenská, Martin 2002-2006.

- Dolinský J., Cirkev a štát na Slovensku v rokoch 1918-1945, Dobrá kniha, Trnava 1999.

- Feriancová A., (Ne)nájdená bezpečnost'. Československo, Nemecko a úpravy medzinárodného systému v Európe 1922-1926, Univerzita Konštantína Filozofa, Nitra 2010.

- Gabzdilová S., Školský systém na Slovensku v medzivojnovej Československej republike (1918-1938), Univerzita Pavla Jozefa Šafárika v Košiciach, Košice 2014.

- Hetényi M., Ivanič I., Poznámky k šíreniu kultu sv. Cyrila a Metoda v rokoch 19391945 na príklade mesta Nitra, [in:] Život v Slovenskej republike: Slovenská republika 1939-1945 očami mladých historikov IX, ÚPN, Bratislava 2010.

- Just P., Language problems as the conflict issues of Slovak-Hungarian relations, "Annual of Language \& Politics and Politics of Identity", 2007, no. 1. 
- Kadlecová M., Poměr státu a církví, [in:] Dějiny Československého státu a práva (19181945), Masarykova univerzita, Brno 1992.

- Kamenec I., Slovenský stát 1939-1945, Anomal, Praha 1992.

- Kičková A., Runcimanova misia a Československo v roku 1938, [in:] České, slovenské a československé dějiny 20. století IV, UHK, Hradec Králové 2009.

- Letz R. Katolícka cirkev a vznik Slovenského štátu, [in:] Rozbitie alebo rozpad? Historické reflexie zániku Česko-Slovenska 1939, eds. V. Bystrický, M. Michela, M. Schvarc, Veda, Bratislava 2010.

- Michela M., Percepcia svätého Štefana na Slovensku v medzivojnovom období, [in:] Pamět míst, událostí a osobností: historie jako identita a manipulace, Historický ústav AV ČR, Praha 2011.

- Mikulášová A., Palárik M., Oslavy piateho výročia vzniku slovenského štátu v nitrianskom regióne, [in:] Slovenské národné povstanie, ed. M. Syrný, Múzeum SNP, Banská Bystrica 2014.

- Molnár I., Život a martýrska smrt’ Jánosa Esterházyho, Méry Ratio, Šamorín 2012.

- Mulík P., Katolícka cirkev a politika Slovenskej republiky 1939-1945, [in:] Slovenská republika (1939-1945), Matica slovenská, Martin 2000.

- Mulík P., Úsilie o zriadenie slovenskej cirkevnej provincie od roku 1939 a jej vývoj po súčasnost', [in:] Katolícka cirkev a Slováci. Úsilie Slovákov o samostatnú cirkevnú provinciu, Bernolákova spoločnost', Bratislava 1998.

- Pekár M., Základné východiská menšinovej politiky na Slovensku od roku 1918 po súčasnost', [in:] Národnostná politika na Slovensku po roku 1989, ed. Š. Šutaj, Universum, Prešov 2005.

- Pekár M. et al., Ethnic Minorities in Slovakia in the years 1918-1945, Universum, Prešov 2011.

- Petranský I. A., Katolícka cirkev na Slovensku a povstanie roku 1944, [in:] Slovenská republika 1939-1945 očami mladých historikov III, Univerzita Cyrila a Metoda, Trnava 2004.

- Petranský I. A., Katolícka cirkev v období prvej Slovenskej republiky, [in:] Slovenská republika 1939-1945 očami mladých historikov I, Univerzita Cyrila a Metoda, Trnava 2002.

- Popély G., A kisebbségi magyar pártpolitika megújulása a harminc évek a első felében, „Regio", 1990, no. 3.

- Rychlík J., Perzekúcia odporcov režimu na Slovensku 1938-1945, [in:] Slovenská republika 1939-1945 očami mladých historikov IV, Univerzita Mateja Bela, Banská Bystrica 2005.

- Sidor K., Šest' rokov pri Vatikáne, PA, Scranton, 1947.

- Simon A., Vplyv štátoprávnych a politických zmien z konca roka 1938 a zo začiatku roka 1939 na postavenie mad'arskej menšiny (so zvláštnym zretelom na bratislavských Mad'arov), [in:] Rozbitie alebo rozpad?, eds. V. Bystrický, M. Michela, M. Schvarc, Veda, Bratislava 2010.

- Suško L., Evanjelická cirkev augsburského vyznania na Slovensku 1938/1939v zrkadle cirkevnej tlače, „Historický časopis”, 2001, no. 1.

- Šmihula V., Postoj evanjelickej a.v. cirkvi k vojnovému Slovenskému štátu, [in:] SNP 1944 - vstup Slovenska do demokratickej Európy, Múzeum SNP, Banská Bystrica 1999. 
- Šprocha B., Tišliar P., Demografický obraz Slovenska v sčitaniach ludu 1919-1940, Tribun EU, Brno 2012.

- Šprocha B., Tišliar P., Demogeografický profil náboženského vyznania obyvatel'stva Slovenska za posledných 100 rokov, [in:] Populačné štúdie Slovenska, Muzeológia a kultúrne dedičstvo o.z., Bratislava 2014.

- Šprocha B., Tišliar P., Štruktúry obyvatel'stva Slovenska v rokoch 1919-1940, Infostat, Bratislava 2009.

- Šutaj Š., Mad’arská menšina na Slovensku v 20. storočí, Kalligram, Bratislava 2012.

- Šutaj Š., Mad’arská menšina na Slovensku v rokoch 1945-1948, Veda, Bratislava 1993.

- Tišliar P., Formy organizovania vysṫahovalectva zo Slovenska po vzniku Československej republiky, [in:] Migračné procesy Slovenska (1918-1948), Belianum, Banská Bystrica 2014.

- Tišliar P., Historical demography in Slovakia in the last century, "European Researcher", 2012, no. 3.

- Tišliar P., To historical demography and demographic history in Slovakia, "Historický časopis", 2011, no. 2.

- Tóth A., Novotný L., Stehlík M., Národnostní menšiny v Československu 1918-1938, Univerzita Karlova, Praha 2012.

- Vaško V., Neumlčená. Kronika katolické církve v Československu po druhé světové válce I. Zvon, Praha 1990.

- Vadkerty K., Mad’arská otázka v Československu 1945-1948. Dekréty prezidenta Beneša a ich dôsledky na deportácie a reslovakizáciu, Kalligram, Bratislava 2002.

- Vatikán a Slovenská republika 1939-1945. Dokumenty, eds. I. Kamenec, V. Prečan, S. Škorvánek, Slovac Academic Press, Bratislava 1992.

- Vietor M., Dejiny okupácie južného Slovenska. Vydavatel'stvo SAV, Bratislava 1968.

- Vilhan M., Postoje katolíckej cirkvi na Slovensku k politickým režimom v rokoch 1939-1951, [in:] SNP 1944 - vstup Slovenska do demokratickej Európy. Múzeum SNP, Banská Bystrica 1999.

- Zelenák P., Krajinská krestáansko-socialistická strana, [in:] Politické strany na Slovensku 1860-1989, ed. L. Lipták, Archa, Bratislava 1992, pp. 150-158.

- Zel’ová A., Etnická identita mad'arskej menšiny na Slovensku, [in:] Etnické menšiny na Slovensku, ed. V. Paukovič, Spoločenskovedný ústav SAV, Košice 1991.

- Zprávy Štátneho plánovacieho a štatistického úradu, 1946, vol. 1, no. 1.

Summary: The confession of Hungarian minority in the Slovak State only slightly differed from the confession of Slovak majority, however, there were different views on confessional issue of Hungarian minority that reflected unhealthy Czech-Slovak-Hungarian relationships. A religious sphere relating to the Hungarian minority reflected political and social development and an overall ratio of the state and churches. In reconstruction of this relationship, the study was based on a contradictory attitude of the first Republic towards churches. The study, therefore, apart from the period of 1939-1945, records the course of events in the Czechoslovak Republic during the interwar period. There was a change after 1939, when the most significant church in Slovakia - the 
Roman Catholic - became a support of political regime. Even in the ecclesiastical area associated with Hungarian community, the principle of reciprocity applied between Slovakia and Hungary was a decisive one. A conflict relationship of state apparatus or majority population towards the public worships in the Hungarian language was substantial. The results of this work are mainly based on the archive research, as well as the research of press at the time.

Keywords: Hungarian minority, religious question, Czechoslovakia, Slovak State

\section{Mniejszość węgierska i kwestia wyznaniowa w Republice Czechosłowackiej i państwie słowackim okresu międzywojennego}

Streszczenie: Wyznanie mniejszości węgierskiej na Słowacji tylko w niewielkim stopniu różniło się od wyznania większości słowackiej. Istniały jednak różne opinie na kwestię wyznaniową mniejszości węgierskiej, które odzwierciedlały niezdrowe relacje między Czechami, Słowacją i Węgrami. Sfera religijna odnosząca się do mniejszości węgierskiej odzwierciedlała polityczny i społeczny rozwój i ogólną relację państwa i kościoła. W celu ukazania tej sytuacji, artykuł został oparty na przedstawieniu sprzecznej postawy pierwszej Republiki wobec kościoła. W opracowaniu - oprócz lat 1939-1945 - przedstawiono ciąg wydarzeń mających miejsce w Republice Czechosłowackiej w okresie międzywojennym. Po roku 1939 nastąpiła zmiana, kiedy to najważniejszy kościół w Słowacji (rzymskokatolicki) wsparł polityczny reżim. Nawet na terenach kościelnych mających związek ze społecznością węgierską zasada wzajemności między Słowacjąa a Węgrami była decydująca. Konfliktowa postawa aparatu państwa czy ludności stanowiącej większość wobec kultu publicznego obecnego w języku węgierskim była znacząca. Wyniki opracowania są oparte na badaniach archiwalnych oraz na analizie ówczesnej prasy.

Słowa kluczowe: mniejszość węgierska, kwestia religijna, Czechosłowacja, państwo słowackie 